\title{
A UNIVERSALIDADE DA HERMENÊUTICA
}

\author{
Custódio Luis S. de Almeida*
}

SINTESE - Este artigo pretende discutir a universalidade do problema hermenêtutico na perspectiva de H. G. Gadamer. O ponto de partida é a reviravolta ontológica da hermenêutica realizada por Heidegger. Por isso, tomando a ontologia fundamental como referência inicial, Gadamer apresenta a historicidade como principio hermenêutico básico e descobre na linguagem o lugar filosófico por excelência, pois ela é, ao mesmo tempo, acontecimento, especulação e abertura. Gadamer considera que no centro especulativo da linguagem acontece a mais radical experiência humana: a experiência da finitude.

PALAVRAS-CHAVE - Hermenèutica. Gadamer. Universalidade. Historicidade. Linguagem.
ABSTRACT - My aim throughout this article is creating a discussion about the universality of the hermeneutic problem in H. G. Gadamer perspective. The initial context is Heidegger's ontological turn. Gadamer undertakes of the fundamental ontology, showing that historicity is the most important principle of the hermeneutic and he discovers in the language the most preeminence philosophical place, because it is, at the same time, happening speculation and opening. In the central point of the language happens the most universal experience to the human beings: the end's experience.

KEY WORDS - Hermeneutic. Gadamer. Universality. Historicity. Language.

"Mau hermeneuta é aquele que acredita que pode ou deve ficar com a última palavra" (H. G. Gadamer).

\section{A ontologia fundamental como pressuposto do círculo hermenêutico}

Deveremos começar com uma questão ${ }^{1}$ básica e necessária ao entendimento do que queremos expor: o que torna possivel a interpretação? Responder a ela significa apresentar o fundamento ontológico da hermenêutica filosófica, o que para Heidegger corresponde à ontologia fundamental ${ }^{2} \mathrm{e}$ para Gadamer significa o

* Professor de Filosofia da Universidade Federal do Ceará (UPCE) e doutorando em Filosofia pelo Curso de Pós-Graduação da puCrs.

1 Começar essa análise com uma questão significa assumir que hả uma procura e "toda procura retira do procurado sua direçăo prévia”. Na ontologia fundamental de Heidegger a direçăo prévia de qualquer interpretaçăo é o Ser (Cf. Heidegger, Ser e Tempo, § 2, p. 30).

2 A ontologia fundamental trata da questão do ser retirada do plano metafísico da filosofia clássica e da filosofia da subjetividade. Para Heidegger o grande erro da tradição metafísica foi o esquecimento do Ser, para ele, a pergunta pelo Ser é a fundamental pergunta esquecida na tradiçào, que 
lugar prévio da compreensão. O ponto de partida é a afirmação: o lugar de onde falamos é o mundo, ${ }^{3}$ onde desde sempre já nos encontramos. 0 mundo ${ }^{4}$ é a manifestação do possível, do sentido e da linguagem. O mundo é a abertura na qual moramos; não è uma entidade fisica, mas o lugar no qual estamos dispostos. ${ }^{5} \mathrm{O}$ mundo é o passado trazido a mim como herança e é o meu projeto de futuro. $\mathrm{O}$ mundo é a temporalidade que torna possivel o tempo, a espacialidade de onde percebo o espaço, a historicidade que propicia a história; é a realidade que esclarece o real. Nesse sentido, somente o ente mundano ${ }^{6}$ é dotado dos caracteres do mundo; por isso, o eis-ai-ser é o único ente que pode dialogar, e dialogando ele se faz capaz de interpretar; assim, qualquer tarefa de interpretaçăo já deve se situar no chão ontológiço da presença do ser - lugar da possibilidade e do sentido - e somente neste lugar é possivel falar sobre a verdade.

A virada ontológica da hermenêutica filosófica, iniciada com Heidegger, ${ }^{8}$ no século XX, constitui-se como núcleo central para o entendimento do circulo her-

apesar disso forneceu várias denominaçōes do Ser que esconderam o seu sentido originário. Assim, todas as vezes que o Ser foi dito do alto de uma filosofia coisificante ou de uma teoria subjetivante (a teoria do conhecimento da filosofia moderna), ai mesmo ele foi esquecido. O sentido do Ser, para a ontologia fundamental, nåo é um objeto dado, que deve ser descrito ou apropriado (tornado propriedade); da mesma forma não é uma criação subjetiva. Por isso, a ontologia fundamental significa a recuperaçâo da pergunta pelo Ser, mas, a partir da existência finita do eis-ai-ser, o que transforma o caminho de o acesso ao Ser em via negativa: o Ser năo se esgota jamais na finitude, mas é exatamente a finitude que o descobre como infinito, isto é, negando qualquer positividade do Ser se estar revelando-o, porque ele sempre será mais do que se possa dizer sobre ele.

3 A palavra mundo aqui tem o sentido heideggeriano, portanto, "mundo năo significa o universo fisico dos astrônomos, mas o conjunto de condiçōes geográficas, histónicas, sociais e econômicas, em que cada pessoa está imersa". (Cf. Stein, E. - Heidegger - vida e obra. In: Heidegger, Editora Abril, Coleção Os Pensadores.) O mundo é o sentido.

4 Heidegger explica que a palavra grega arkhé é o principio original que "designa aquilo de onde algo surge" e nesse sentido podemos entender a palavra mundo, o lugar das possibilidades, o lugar do sentido. É preciso ter claro, contudo, que esse principio original não pode ser esquecido em função daquilo que dele surge, pelo contrário, sua presença deve sempre imperar. (Ct. Heidegger - Oue é isto - a filosofia?. In: Heidegger, Conferéncias e escritos fillosóficos, p. 21).

5 Heidegger compreende "disposição" no sentido da palavra grega phátos. Ele explica: "traduzimos habitualmente phátos por paixão, turbilhão afetivo. Mas phátos remonta a pdiskhein, sofrer, agüentar, suportar, tolerar, deixar-se levar por, deixar-se com-vocar por. É ousado, como sempre em tais casos, traduzir phátos por dis-posição, palavra com que procuramos expressar uma tonalidade de humor que nos harmoniza e nos com-voca por um apelo" (Ct. Heidegger, op. cit., p. 23).

6 Deve-se entender as expressōes ente mundano e ente do mundo como sinônimas de eis-ai-ser (Dasein).

7 O eis-af-ser é a tradução de Dasein que será utilizada no texto. Ela significa a manifestaçăo do Ser no mundo, abertura do sentido, lugar da compreensăo. eis-al-ser é, dinamicamente, 0 ai do ser, a casa do ser, o ser-aí - outra tradução utilizada. Heídegger usa a palavra Dasein para designar o ente mundano, o ente que é marcado pelas caracteristicas a que ele denominou existenciais, exatamente por serem designações ontológicas - nesse sentido ele quis diferenciar os existenciais que expressam a ontologia fundamental das categorias que sâo formulaçōes da metafísica e da filosofia da consciência. Os existenciais são os modos de ser do Dasein. O Dasein năo é um sujeito para quem existe um objeto, mas um ser no ser. O Dasein designa um lugar onde a questâo do ser surge, o lugar da manifestaçăo (Cf. Ricouer, P. Interpretação e ideologias, p. 30). Os existenciais são os modos de ser do Dasein.

8 Tomar Heidegger como ponto de partida para o entendimento da hermenêutica filosófica e do seu núcleo duro: o círculo hermenêtutica, é assumir a distinçăo feita por Gadamer sobre os dois grandes campos da hermenêutica filosófica contemporânea: o campo epistemológico, no qual se pode incluir Schleiermacher e Dilthey e o campo ontológico onde se situam Heidegger e Gadamer. 
menêutico, como estrutura da compreensão e de suas condições de possibilidade. Levar em conta a prévia estrutura da compreensão elaborada por Heidegger resulta no entendimento do que hoje se denomina reviravolta hermenêutica da filosofia contemporânea e, portanto, significa situar a hermenêutica na e com a tradição filosófica ocidental.

A elaboração de Ser e tempo é o resultado de um diálogo profundo de Heidegger com a filosofia desde Aristóteles, remetendo aos pré-socráticos, passando pela metafísica medieval e pela filosofia da subjetividade moderna - desde de Descartes - chegando a Wittgenstein e à fenomenologia husserliana do século XX. Nesse diálogo Heidegger se fez ontólogo para se levantar contra a ontologia, assumiu o pensamento transcendental contra os transcendentais (Kant e os neokantianos), identificou-se como fenomenólogo contra a fenomenologia e, contra a antropologia, definiu-se como antropólogo, fazendo a analítica-existencial do ente do mundo - o Dasein (o eis-ai-ser). ${ }^{9}$ Lembrar esta trajetória significa destacar essa obra monumental da filosofia como lugar de ruptura fecunda, a partir de onde a hermenêutica se destaca como possibilidade nova de leitura e compreensão das questões que marcam a filosofia ocidental: o Ser, o Mundo e o Homem.

A hermenêutica filosófica remete ao círculo da compreensão, entendido como boa circularidade. Dessa forma, compreender não é uma atividade linear a que se exige a busca genética e teleológica do que se quer compreender, mas é a presença no mundo ${ }^{10}$ do ente que compreende. A circularidade é o núcleo da compreensão possivel que transpõe qualquer idéia de começo e fim e se situa no presente; isso significa que o passado e o futuro estâo sempre presentes como horizontes do presente, como possibilidades de compreensão. Antes de entender 0 passado ou vislumbrar o futuro, compreender é uma vivência do presente, que requer conhecimento de tudo que o envolve; assim, a partir do presente o passado se desvela e o futuro se antecipa.

O grupo dos "existenciais" 11 heideggerianos explicita a estrutura prévia da compreensäo e prepara a virada ontológica da hermenêutica. $O$ circulo hermenêutico se abre com a consciência da finitude e se articula no diálogo que estrutura qualquer compreensão possivel. No entanto, a finitude, como existencial, é trazida ao entendimento à medida que os outros "existenciais" vão sendo expostos; há uma recorrência constante entre os "existenciais" usados na compreensão do círculo, de tal forma que todos eles se imbricam e significam na relação mútua que mantêm entre si.

O ente que compreende é aquele marcado estruturalmente pela possibilidade de compreender. Não há projeto de compreensão possivel sem a possibilidade

9 Ct. Stein, Seis estudas sobre Ser e Tempo, p. 10.

10 A expressão "presença no mundo" significa a participação efetiva do ente mundano na história, a comunhảo com o horizonte de sentido que marca o tempo histórico em que este ente está inserido. $O$ mundo no qual estou presente é o mundo ao qual eu pertenço e que determina o meu ver e o meu escutar; é o mundo das minhas possibilidades teóricas e práticas.

11 Heidegger chama de existenciais as caracterizações ontologicas do ente que revela o ser, o Dasein. que pode ser traduzido como ser-ai ou como o els-af-ser. A primeira traduçāo vem literalmente do francês être-là e é usada no Brasil pelo prof. Ernildo Stein (UFRGS/PUCRS), a segunda tradução pode ser encontrada nos textos do prof. Manfredo de Oliveira (UFC). Os existenciais são as características do eis-af-ser que remetem ao ser e, por isso, permitem ao eis-aj-ser falar do ser e descobri-lo. 
como nomeação ontológica. ${ }^{12}$ Os acontecimentos da vida, o conhecimento do mundo, a formação de juizos lingüisticos e tudo mais que pode-vir-a-ser têm como antecedente necessário a possibilidade de ser. Se o eis-aí-ser pode compreender o mundo e manifestar sentido é porque seu modo de ser no mundo é possibilidade; 0 que pode ser só é possivel por sua determinação ontológica imanente. Aqui é preciso destacar a possibilidade de transcendência como característica imanente. E só se torna possibilidade porque a imanência do eis-ali-ser já é sempre marcada pela transcendência do Ser. ${ }^{13}$ Nesse sentido, a possibilidade não é uma entidade externa autônoma que se impōe de fora aos entes do mundo, mas é uma marca intrinseca do eis-aí-ser, ${ }^{14}$ só o eis-ai-ser é ser de possibilidade, isto quer dizer que somente o ente do mundo vive na esfera do sentido, só ele tem o caráter estrutural da abertura.

A lingüisticidade é o lugar da abertura possibilitada pela linguagem ${ }^{15}$ à medida que põe o eis-aí-ser diante do mundo, fazendo-o alteridade. A lingüisticidade é a diferença como instância estruturante da identidade; é porque o modo de ser do eis-al-ser é a lingüisticidade que podemos falar do outro, do estranho, do diferente. O outro não é outro porque existe enquanto ente ao lado de outros entes, mas porque é reconhecido como outro pelo eis-ai-ser que, na sua finitude, abre-se à diferença. A lingüisticidade não possibilita apenas a comunicação intersubjetiva através de uma língua determinada, mas è a própria comunicação como "existencial", para além de formas empiricas de comunicação; a lingüisticidade não é apenas o lugar de realização da fala, ${ }^{16}$ mas é onde se realiza o encontro com a

12 Devemos entender ontológico aqui sempre no sentido da ontologia fundamental, ou seja, é ontológico aquilo que se fundamenta no Ser e a ele pertence.

13 Não se trata de um jogo de palavras, para Heidegger o modo de ser do Dasein torna possivel tudo quanto o Dasein pode realizar, portanto, se a transcende̊ncia é uma possibilidade do eis-af-ser é porque seu modo de ser no mundo (enquanto imanência) já é marcado pela transcendência. A transcendência é um movimento que o eis-aíser é capaz de realizar e não um objeto transcendente exterior.

14 A ênfase dada aqui na possibilidade como marca ontológica do eis-ai-ser se explica melhor por contraste entre este ente e os outros entes. Heidegger diferencia o els-af-ser como ente mundano dos outros entes como intramundanos ou simplesmente dados, para estes outros entes a passibilidade inexiste, eles são pura determinaçăo, portanto, os demais entes são fechados e indispostos, não manifestam o sentido, podemos dizer que săo completos na sua determinaçăo, enquanto os entes mundanos sâo incompletude, tarefa, abertura. Assim. por exemplo, para a vaca não há a esfera do possivel, ela está presa na sua determinação.

150 melhor lugar para se compreender o Ser é no próprio ser feito linguagem. Se em Ser e Tempo Heidegger buscou o eis-af-ser como porta de acesso ao Ser, agora, é o Ser que se torna a porta de entrada para a qualquer compreensăo possivel. Stein esclarece que quando se fala de linguagem não se deve referir apenas ao seu sentido apofäntico (o sentido de uma proposiçăo), mas, principalmente, ao sentido hermenéutico (aquele que fundamenta a verdade das proposiçōes), à medida que a linguagem é "o mundo sobre o qual falamos". Trata-se, portanto, "de falar do mundo e nos darmos conta de que não podemos falar do mundo a nåo ser falando da linguagem" (Cf. Stein, Aproximaçōes sobre hermenêutica, p. 14).

16 Normalmente, reduz-se a esfera da linguagem a uma forma de comunicação através de uma determinada língua, mas o sentido da linguagem transcende os modos empíricos de comunicação e se define como instância ontológica do eis-al-ser que, por isso mesmo, é abertura ao outro, à diferença, ao encontro. Assim, a possibilidade que o eis-aj-ser tem de se dispor ao outro, de se por diante do diferente, afirma sua linguisticidade, tornada possivel pelo acolhimento do ser como linguagem. 
diferença, por isso, a hermenêutica gadameriana afirma o ser como linguagem ${ }^{17} \mathrm{e}$, exatamente porque o ser é linguagem é que o modo de ser do eis-ai-ser é lingüisticidade.

A lingüisticidade é o modo de ser do eis-af-ser que abre o mundo como realidade, "entretanto, somente com base num mundo já aberto é que o real pode vir a ser descoberto ou ficar encoberto". ${ }^{18}$ A realidade é sempre extensão da linguagem, porque, pela linguagem, o eis-al-ser ler o mundo, articula-o e articula-se nele. Aqui, a realidade é a marca ontológica do olhar do ente mundano; por ela, o real $^{19}$ emerge como realidade. A realidade brota na linguagem e revela-se na verdade. Há um imbricamento entre realidade e compreensão, pois tudo que é realidade é compreensivel: a compreensão é o modo de ser do eis-al-ser e a realidade é a compreensão do ser que toma os entes acessiviveis. A realidade é instância ontológica do ente mundano, que "desde o início é colocado diante de um apreender, de um presumir, de um assegurar-se e crer, de uma atitude que, em si mesma, já é um modo derivado de ser-no-mundo". ${ }^{20}$ A realidade é resistência ${ }^{21}$ ou, como diz Heidegger, "é o conjunto de todas as resistências", isso significa que ela não é a apreensão esgotante do mundo, mas é o mundo apreendido como possibilidade sempre nova, como abertura. Há algo que sempre resiste, que sempre escapa ao completo conhecimento, por isso, a realidade é a contínua tarefa do eis-ai-ser, é o empenho interminável em busca da apreensão.

A realidade é revelada pelo Ser e o Ser é verdade, desse modo, a verdade é o que possibilita a revelação da realidade. O problema da verdade remete diretamente à ontologia fundamental porque "encontra-se, justificadamente, num nexo originário com o ser". 22 Ora, a verdade como revelação do ser jamais pode ser entendida de forma objetal - como algo que se presentificou e se impõe de uma vez para sempre - a verdade será sempre transcendental, ela é o ser que revela o mundo, é o lugar da doação do sentido descoberto na realidade. A verdade manifesta-se no aí (existência) do eis-aí-ser, mas näo pode ser reduzida ao manifestado; o revelado afirma a verdade sem, contudo, revelá-la. A verdade é o ser que

17 Cf. Gadamer, Verdad y metodo I, p. 567.

18 Cf. Heidegger, Ser e Tempo, \$ 43, p. 269.

19 Apenas como recurso de esclarecimento fazemos aqui uma distinção entre real e realidade. A realidade é modo de ser do eis-ai-ser porque este ente do mundo só pode ver o mundo como realidade. Tudo que emerge como do ser é realidade, pois já está inserido na esfera da linguagem e, por isso, tem sentido. O real é uma mera suposição, pode-se dizer que é aquilo que ainda não emergiu como realidade, mas que poderá vir a ser. O real seria o escuro que, ao ser lluminado, perde a escuridaa e torna-se claridade, e a realidade é a claridade; como năo vemos no escuro, então, o que vemos não é real, mas realidade. Heidegger explica essa diferença da seguinte forma: "O fato de a realidade se fundar ontologicamente no ser do ejs-af-ser não pode significar que o real só poderá ser em si mesmo aquilo que é se e enquanto existir o "eis-ai-ser'." (Cf. Heidegger, Ser e Tempo, § 43, p. 279).

20 Cf. Heidegger, Ser e Tempo, \$ 43, p. 272.

21 Resistência, para Heidegger, é uma instância determinadora da realidade, definida por ele como aquilo que "vem ao encontro como não deixar passar [...], como impedimento da vontade de passar", então, pela resistência "abre-se algo pelo que impulso e vontade se empenham". "Do ponto de vista ontológico, a experiência de resistência, ou seja, a descoberta daquilo que resiste a um es. forço, só é possivel com base na abertura de mundo" (Cf. Heidegger, Ser e tempo, § 43, p. 277).

Cf. Heidegger, Ser e Tempo, § 44, p. 281. 
revela e năo os entes revelados. Ora, porque a verdade é ser ideal ${ }^{23}$ é que a filosofia "se determina como ciência da verdade". ${ }^{24}$

A manifestação transcendental da verdade se dá no núcleo especulativo do diálogo e é, por isso que o diálogo ao se constituir como momento fático de linguagem já está pressuposto como instância ontológica. ${ }^{25} \mathrm{Na}$ especulação própria do diálogo os "existenciais" são efetivados; por isso, o diảlogo é possibilidade, aberturà e disposiçăo, nele se explicita a tensão entre empírico e transcendental, entre o "eu" e o "tu", entre o familiar e o estranho. O diálogo é o lugar do projeto, do sentido e da compreensão, pois é nele que se dão as relaçōes de identidade e diferença na qual se abrem os horizontes do mundo. O diálogo é a necessária presença do ente mundano no mundo, é o "ai" ineliminável do Ser, como diria Heidegger, é o "sendo" do Ser; dessa forma, o diálogo é a experiência da finitude, é a marca da temporalidade que dá sentido à história e é a instância fundante da historicidade. $\mathrm{O}$ diálogo é a realidade na lingüisticidade; é o mundo feito realidade através dà mediação da linguagem.

O diálogo ontológico-fundamental é o encontro do eis-aí-ser com o estranho, o indizivel, o inefável, é, pois, a angústia e a tensão inelimináveis na existência, que se constitui como via de acesso ao Ser. Angustiado o eis-al-ser é negativo, por isso, ele rejeita tudo aquilo que o transforma em ser limitado, preguiçoso, covarde, banal, anônimo, vulgar, insignificante, trivial, exilado, inautêntico. A inquietude proviocada pela angústia se toma o elemento estruturante do homem na história. Assim, o diálogo é o fundamento ontológico do círculo hermenêutico que, por isso mesmo, tem a circularidade da espiral, pois não se fecha - tautologicamente - sobre si mes̉mo. O círculo hermenêutico no diálogo se constitui como o lugar do silêncio e da escuta do Ser que manifesta seu sentido na linguagem.

$\mathrm{Na}$ analítica do eis-ài-ser Heidegger determinou a pergunta ontológica fundamental sobre o Ser e, dessa forma, o Ser reaparece como o lugar da compreensão, do sentido e dà verdade. Desse ponto parte Gadamer. Na busca da explicitação do circulo hermenêutico, a compreensão àcontece como aproximação do Ser. A compreensão nunca é privada de mais compreensão; por isso, nenhuma interpretação é definitiva. Interpretar è a dialética dò encontro da infinitude pela fínitude, interpretar é a hermenêutica de morar no tempo, na história e na linguagem; interpretar é uma tarefa negativa permanente do homem.

23 Heidegger afirma a filosofia como ciência da verdade, entendida como ideal, e explica: "se o título idealismo significar o mesmo que compreender a impossibilidade de se esclarecer o Ser pelo ente mas que, para todo o ente, o Ser já é o 'transcendental', então, é no idealismo que reside a única possibilidade adequada de uma problemática filosófica" (Cl. Heidegger, Ser e Tempo, § 43, p. 274).

24 Cl. Heidegger, Ser e Tempo, § 44, p. 280.

25 Não se trata aqui de diálogo empírico, das conversas entre pessoas; mas do diálogo que torna os diálogos empińcos possíveis. O modo de ser do eis al-ser é diảlogo; è o conflito interminável dos entes finitos. No diálogo vem à tona o ser para a morte de Heidegger. A predestinação para a morte é a instáncia produtora da angústia visceral de estar predestinado ao vazio e ao Nada. A angústia é a negatividade onipresente que "envolve o homem com um sentimento de estranheza radical" (Cf. Stein, B. In: Heidegger - vida e obra, Coleçăo Os Pensadores). 


\section{O círculo hermenêutico no diálogo}

\subsection{O pré-juízo como condição necessária à compreensão do círculo hermenêutico}

Gadamer ínicia a fundamentação da sua teoria da experiểncia hermenêutica fazendo uma análise do conceito de prejuízo. Ele toma como pressuposto de sua elaboração a descrição, feita por Heidegger, da estrutura prévia da cornpreensão. Ora, a referência direta a Heidegger na teoria gadameriana não implica apenas a continuação de uma análise explicitamente aceita como correta ${ }^{26}$ e que, por isso, serve de pressuposto ontológico à teoria da experiência hermenêutica, mas significa também uma recuperaçăo da analitica heideggeriana do eis-ai-ser como fio condutor para uma nova interpretaçăo que, para Gadamer, é o chão firme ${ }^{27}$ da compreensão da experiência hermenêutica. Isso quer dizer que além de sustentar a analitica fenomenológica feita por Heidegger como "lugar" ontológico da compreensão, Gadamer avança sua análise, acrescentando ao sentido ontológico dos "existenciais" heideggerianos o sentido hermenêutico, ${ }^{28}$

Em Gadamer a historicidade se torna o princípio hermenêutico fundamental. Isso significa que a condição de possibilidade da experiência hermenêutica é o caráter histórico do intérprete e do interpretado. O conceito de historicidade reúne os nexos necessários à compreensão do circulo hermenêutico, porque retira a compreensão da esfera epistemológica do pensamento e a põe na esfera ontológica do Ser. ${ }^{29} \mathrm{~A}$ interpretação é ao mesmo tèmpo posiçäo, previsãão e añtecipação, que são marcas constitutivas da temporalidade. Desse forma, a interpretaçăo nâo é um modo de agir que dependa simplesmente do arbitrio de um sujeito que se apropria, sempre ativamente, dos objetos a serem interpretados, mas é um ato de convalidação, por isso, Gadamer afirma que "aquele que quer compreender um texto realiza sempre um projetar", pois o sentido manifesto não é um ato de construção subjetiva, mas é uma posição que precisa ser continuamente revisada

26 Cf. Gadamer, Verdad y metodo I, p. 336.

27 Cf. id. ibid., p. 335 .

$28 \mathrm{Na}$ compreensão hermenêutica gadameriana, o eis-af-ser heideggeriano torna-se o intérprete e passa a ser um ente histórico, o próprio homem que compreende. Assim, podemos entender as afirmaçōes: "Aquele que quer compreender um texto rẻaliza sempre um projetar. Assim como aparece no texto um primeiro sentido, o interrprete projeta em seguida o sentido do todo"; "o que se exige é simplesmente estar aberto à opinião do outro ou à do texto"; "aquele que quer compreender um texto tem que estar em principio disposto a deixar-sé dizer algo por ele" (Cf. Gadamer, Verdad y metodo I, p. 333-335). Percebemos nas citaçōes acima o uso das palavras "projetar", "aberto", "disposto" no sentido ontológico-hermenêutico, que transpōe o sentido ontológico aberto por Heidegger. Vale acrescentar que, para Gadamer, o Dasein heideggeriano năo ê a substancialidade (histótia, tradição), mas o lugar da compreensão (Cf. Verdad y Metodo II, 350).

29 Para Gadamer a interpretaçáo correta começa na abertura ao outro, ao texto que deve ser interpretado e só alcança suas verdadeitas possibilidades quando as opiniões prévias com as quais se inicia não são arbitrárias. Abrir-se ao texto significa iniciar o processo de convalidaçảo dos juizos prévios através do confronto com "a coisa mesma" que deve ser compreendida, o que implica despir-se da arbitrariedade das opiniōes prévias. "Toda interpretação correta tem que proteger-se contra a arbitrariedade das ocorrências e contra a limitaçăo dos hábitos imperceptiveis do pensar e orientar-se para "a coisa mesma" (Cf. Gadamer, Verdad y metodo I, p. 332 e 333). 
e que por ser, inicialmente, previsão e antecipação ainda carece de revisões, substituiçōes e adequações. O intérprete não é senhor da história, mas sim seu pastor, pois encontra-se ele mesmo mergulhado nela.

$\mathrm{Na}$ verdade a experiência hermenêutica não anula a subjetividade, mas despe-a do seu senhorio, afirmado na filosofia da consciência. ${ }^{30}$ A experiência hermenêutica não exige, por outro lado, uma postura passiva do intérprete, mas, ativa-o a se dar conta dos seus próprios preconceitos. Dar-se conta dos juízos prévios é encontrar a própria historicidade e ter consciência da finitude. Somente "ai" tem inicio o processo de compreensão do ser e, a "coisa mesma" a ser interpretada começa a se manifestar. Na relação que se estabelece entre o intérprete e o texto, os juizos prévios vêm à tona, e adequá-los à "coisa mesma" é a tarefa da compreensão. $^{31} \mathrm{~A}$ atividade de quem interpreta implica abertura à opinião do outro ou do texto, em disposição para deixar-se dizer algo por ele e no constante reprojetar das opiniōes prévias, que tanto podem ser substituídas progressivamente por outras, mais adequadas à "coisa mesma", como podem ser convalidadas no processo de elaboração.

"Na realidade não é a história que nos pertence, mas somos nós que pertencemos a ela. Muito antes de nos compreendermos a nós mesmos na reflexão, compreendemonos já de uma maneira auto-evidente na familia, na sociedade e no estado em que vivemos. A lente da subjetividade é um espelho deformante. A auto-reflexão do individuo não é mais que uma chispa na corrente fechada da vida histórica. Por isso, os prejuizos de um individuo são, muito mais que seus juizos, a realidade histórica de seu ser." 32

A primeira tese da citação: nós pertencemos à história, faz derivar a segunda: a subjetividade é um espelho deformante. Ora, o reconhecimento de que somos historicidade e, portanto, pertencemos à história, leva-nos a reconhecer, também, que as nossas opiniões sobre as coisas são, por princípio, produtos da história; assim, não são opiniões exclusivamente nossas e, por esta razão, todo processo de compreensão parte de juízos prévios que se projetam sobre a "coisa mesma" que deve ser compreendida, continua como reprojeção - nisso "consiste o movimento de compreender e interpretar" - e finaliza como convalidação. ${ }^{33}$ Por isso, a compreensão é sempre um projetar que, como abertura, é um deixar-se determinar pelo ser que vai ser compreendido.

A tese subseqüente é derivada da primeira, pois, se pertencemos à história, então, a subjetividade possui lentes determinadas pela história e essas lentes, em

30 "Uma consciência formada hermeneuticamente tem que mostrar-se receptiva desde o principio para a alteridade do texto. Mas essa receptividade não pressupōe nem 'neutralidade' frente às coisas, nem tampouco auto-anulaçăo, mas sim inclui uma matizada incorporação das próprias opiniōes prévias e pré-juizos. O que importa é dar-se conta das próprias antecipaçōes, a fim de que o texto mesmo possa apresentar-se em sua alteridade e obtenha assim a possibilidade de confrontar sua verdade objetiva com as próprias opiniōes prévias" (Cf. Gadamer, Verdad y metodo I, p. 335-336).

31 Cf. Gadamer, Verdad y metodo I, p. 333.

$32 \mathrm{Cf}$. Gadamer, Verdad y metodo I, p. 344. (Grifo meu)

33 Se podemos falar de "objetividade" no círculo hermene̊utico, este conceito deve ser compreendido como a "convalidação obtida pelas opiniōes prévias ao longo de sua elaboração" (Cf. Gadamer, Verdad y metodo I, p. 333). 
principio, se constituem como fator de resistência no processo de interpretação, daí por que o olhar prévio sobre a coisa é marcado pelos prejuizos que, muitas vezes, não são adequados à coisa mesma e precisam ser constantemente confrontados com ela para chegarem à adequação. "A lente da subjetividade é um espelho deformante" enquanto não se dispōe ao confronto e não se abre à opinião do outro ou ao texto, ou seja, enquanto não deixa a "coisa mesma" aparecer, permanecendo na cegueira do isolamento; mas, à medida que as opiniões prévias são reconhecidas, então acontece a projeção sobre a "coisa mesma", ela se descobre e seu sentido se manifesta.

A citação termina com a definição gadameriana de prejuízo: "os prejuizos de um individuo são, muito mais que seus juizos, a realidade histórica de seu ser". Somente entendido dessa forma, esse conceito passa a pertencer à hermenêutica filosófica e faz justiça à historicidade da compreensão. Gadamer apresenta também a definição literal de prejuizo: "Em si mesmo, prejuizo quer dizer um juizo que se forma antes da convalidação definitiva de todos os momentos que são objetivamente determinantes", ${ }^{34}$ e mostra que esta definição pode ser desvirtuada quando se entende que "um juizo que se forma antes da convalidação definitiva [...]" é fruto de uma imposição exterior de uma autoridade - pessoa constituída ou tradição - porque, na verdade, é resultado intrínseco da realidade histórica de um indivíduo.

As afirmaçōes acima correspondem à conclusão da análise dos prejuizos, por isso, recuperar esse conceito é, como diz Gadamer, "fazer justiça à historicidade da compreensão". Gadamer continua mostrando como o conceito de prejuízo se tornou pejorativo a partir da Ilustração e, conseqüentemente, da filosofia da consciência e, em seguida, promove sua reabilitação através dos conceitos de autoridade, tradição e clássico e, dessa forma, explicita a historicidade como princípio hermenêutico.

\subsection{A llustração moderna como fonte do "preconceito contra o preconceito"}

Fazer justiça à historicidade da compreensão é resgatá-la da obscuridade em que foi lançada e mostrar como e por que ela foi desvalorizada pelo dogmatismo da razăo subjetiva. Gadamer analisa a fonte originária do preconceito contra 0 preconceito e, dessa forma, repōe os juízos prévios no seu verdadeiro lugar na experiência histórica. Através do desmonte histórico da llustração moderna, Gadamer encontra a justificativa do sentido pejorativo atribuído aos prejuizos e, ao mesmo tempo, nega sua consistência.

A formulação kantiana que traduz o espirito da Ilustração é: "servi-te de teu próprio entendimento". ${ }^{35}$ Essa formulação afirma a razão subjetiva como árbitro do sentido e da verdade, isto é, em última instância, a decisão pertence ao indivíduo. A direção inicial da crítica da llustração é a tradição religiosa do Cristianismo e a

34 Cf. Gadamer, Verdad y metodo I, p. 337.

35

Cf. Kant, "Resposta a la pregunta: Qué es la nustración?" In: KANT, 1. Fllosolfa de la historia. Buenos Aires, 1964, p. 58-68). Apud Gadamer, op. cit., p. 338). 
Sagrada Escritura, mas a elaboração dessa crítica desemboca na recusa de qualquer autoridade ou tradição. Assim, "a possibilidade de que a tradição seja verdade depende do crédito que lhe concede a razão. A fonte última da autoridade não é a tradição mas sim a razão". ${ }^{36}$

Identificada a fonte do preconceito contra o preconceito, Gadamer nào quer simplesmente desconstruir a razăo ilustrada e retornar ao obscurantismo anterior à Ilustração, ou mesmo recair numa espécie de mito justificador do mundo. Por isso, para ele, apesar de a própria Ilustração ter aberto o caminho para o nascimento de sua crítica, através do movimento romântico alemão, ${ }^{37}$ o romantismo não dá conta de fazer justiça à historicidade, pois, mesmo se contrapondo ao esquema ilustrado de superação do mito pelo logos, continua compartilhando "o prejuízo da llustração e se limita a inverter seus valores tentando fazer valer o velho como velho [...]". Para Gadamer, "esta inversão romântica do padrão de valor da llustração pretende justamente perpetuar o pressuposto da Ilustração, a oposição abstrata de mito e razão". ${ }^{38}$ Para ele, a descoberta da origem dos preconceitos contra os preconceitos na Ilustração "torna possivel uma compreensão adequada da finitude que domina não somente nosso ser homem, como também nossa consciência histórica". ${ }^{39}$ Portanto, Gadamer não compartilha da crítica romântica à Ilustração, porque não se trata apenas de admitir os prejuizos como valores subjetivos, mas como modo de ser do Homem; da mesma forma, não se trata de reificar o passado, mas de reconhecê-lo como via indispensável para a compreensão do presente. Se sou marcado definitivamente pela história é porque o meu modo de ser é historicidade; portanto, posso reprojetá-la, reestruturá-la, redimensioná-la, mas jamais posso negá-la.

A finitude que marca o homem o faz estranho a si mesmo; somente o homem é o outro de si mesmo pela sua condição finita. Isso revela que por estar imerso em tradiçōes, ligado necessariamente ao passado, o homem está sempre condicionado pelo mundo que o determina; assim, a subjetividade não se fundamenta em si mesma, pois, sendo abertura, disposição e projeto, está remetida ao mundo das relações existentes. Portanto, porque pertence ao modo de ser da historicidade a razão não é dona de si mesma e nem é capaz de esgotar a verdade. "Na realidade o pressuposto da misteriosa obscuridade na qual vive uma consciência coletiva mítica anterior a todo pensar é tão abstrato e tão dogmático como o de um estado perfeito de Ilustração total ou de saber absoluto." 40

36 Cf. Gadamer, Verdad y metodo I, p. 339.

37 O movimento romântico alemão, iniciado pela critica à llustraçăo feita por $\mathrm{E}$. Burke, reagiu contra o desmonte das formaçōes históricas do passado: o gótico medieval, a comunidade estatal cristä da Europa, a sociedade feudal, a organização da vida no campo; mas, a explicaçăo para essa reação, segundo Gadamer, é dogmática, pois é fundada na valorizaçào do velho porque é velho, revelando uma visão estática de história "que outorga aos tempos passados seu próprio valor e é capaz inclusive de reconhecer sua superioridade em certos aspectos" (Cf. Gadamer, Verdad y metodo I, p. 340342).

Cf. Gadamer, op. cit., p. 341 . 


\subsection{A revalorização hermenêutica da autoridade e da tradição}

A Ilustração difundiu a idéia de uma oposição radical entre o prejuízo e a razão que se estendeu à autoridade e à tradição como fontes dos prejuízos. Por isso é que a reabilitação dos prejuizos implica resgatar a autoridade e a tradição da grave deformação a que foram submetidas. Mas Gadamer reconhece que se deve fazer uma diferenciação entre os prejuizos injustificados e os justificados e, para tanto, "a hermenêutica ensinará a usar corretamente a razão" na distinção entre os preconceitos ilegítimos ${ }^{41}$ - condicionamentos que se referem a uma barreira individual que se opōe à compreensão e que, portanto, são irracionais - dos preconceitos legítimos - os que são resultado da realidade histórica e, nesse sentido, não apenas são racionais, mas são o fundamento da validez da razão.

Quando se rompe com o modelo da relação sujeito-objeto, padrão da llustração e da filosofia da consciência, então percebe-se não apenas a existência de prejuizos legítimos, como também a falsa oposição entre eles e a razão. Desse modo, Gadamer abre caminho para a revalorização da autoridade não apenas como "fonte de prejuízos" legítimos, mas também e, conseqüentemente, como "fonte de verdade". ${ }^{42}$

Năo se pode concordar com aquele tipo de autoridade que usurpa o juizo e, portanto, mostra-se como seu contrário, ou seja, a oposição entre autoridade e razão deve ser eliminada; para tanto, é necessário esclarecer qual a essência da autoridade. Gadamer define autoridade como competência para o exercício de um oficio, como "um ato de reconhecimento e de conhecimento", isto é, reconheço uma autoridade pelo conhecimento que ela detém, por isso, "a autoridade não se outorga, mas sim se adquire e tem que ser adquirida se se quer apelar a ela". É por isso que o "verdadeiro fundamento da autoridade é também aqui um ato da liberdade e da razão". Para Gadamer a autoridade não pode jamais ser entendida como obediência cega, mas como lugar de conhecimento onde os juizos são justificados.

Revalorizar a autoridade, resgatá-la do obscurantismo em que foi lançada pela Ilustração significa reconhecer que, para além do sujeito, a realidade histórica forma nichos de conhecimento que devem ser reconhecidos. Sua validez é a base das justificações racionais do mundo. A autoridade não é o exercício autoritário de uma função, pois "a verdadeira autoridade não necessita mostrar-se autoritária", já que está legitimamente constituida por ato de conquista e nunca se impõe para além do alcance da razão. Assim, Gadamer resgata a autoridade como formação histórica e como síntese de sentido e, em vez de depor a razão em favor da historicidade, mostra que a historicidade é o lugar onde a razão encontra sua validez e liberta-se do dogmatismo do saber absoluto subjetivo.

Com o mesmo argumento a tradição é reabilitada, pois ela é, por excelência, uma forma de autoridade. A tradição não è uma autoridade pessoal, mas "uma pluralidade de vozes nas quais o passado ressoa"; 43 ela é a transmissão do ontem que hoje herdamos; a tradição é o fio condutor da temporalidade que nos põe em

41 Cf. Gadamer, op. cit., p. 346.

42 Cf. Gadamer, op. cit., p. 346.

43 Cf. Gadamer, op. cit., p. 353. 
chão firme pela possibilidade que nela temos de convalidar nossos juizos. A tradiÇão é fonte dos pré-juizos legítimos, portanto, é guardiã da razão e da liberdade; é o lugar comum em que vivemos, pois, sempre e necessariamente, estamos imersos em tradições e nada somos sem elas.

A tradição é o ser que nos determina "mudamente"; somente no silêncio ontológico da tradição podemos escutar a voz do ser que queremos compreender. 0 silêncio e a escuta como caracteristicas ontológicas do eis-aí-ser, segundo Heidegger, revelam-se, para Gadamer, na pluralidade de vozes da tradição. Apesar de suas múltiplas vozes, a tradição é silenciosa; o silêncio é sua autenticidade, por isso, é preciso calar a "tagarelice" - as sujeições e condicionamentos individuais inautênticos - e assumir uma atitude de escuta para que seja possivel ouvir a voz do ser.

Gadamer mostra que a compreensão da consciência histórica nunca é algo totalmente novo, mas um momento novo dentro da tradição. No círculo hermenêutico a tradição é um fator de produtividade: os pré-juizos que se projetam inicialmente, através de um processo de reelaboração e reprojeção contínuas, encontram na tradiçăo a ressonância histórica que os afirma como verdadeiros ou falsos. Assim, o significado verdadeiro não é encontrado apenas ao final da investigação, mas também em seu começo. Desde a projeção inicial até o resultado final, a tradição é o lugar no qual a investigaçăo acontece. Por isso, para Gadamer, não tem sentido supor uma oposição inconciliável entre tradição e razão:

"Na realidade a tradição sempre é também um momento da liberdade e da história. Mesmo a tradiçăo mais autêntica e venerável não se realiza, naturalmente, em virtude da capacidade de permanência do que de algum modo já está dado, mas ainda necessita ser afirmada, assumida e cultivada. A tradição é essencialmente conservação e, como tal, nunca deixa de estar presente nas mudanças históricas. Sem dúvida, a conservação é um ato da razão, ainda que caracterizado pelo fato de não atrair atenção sobre si." 44

O fato de a tradição ser uma pluralidade de vozes silenciosas que não chamam atenção sobre si mesma é que exige do intérprete uma participação ativa no processo de compreensão do ser da "coisa mesma". O intérprete, como investigador, precisa romper a barreira do silêncio através da sua capacidade de escutar $e$ isso significa deixar-se interpelar pela tradiçăo, para entender os nexos que encobrem a "coisa mesma" e descobri-los. Devemos entender a definiçăo: "a tradição é essencialmente conservação", como sendo o fio condutor que leva o intérprete a fundamentar sua descoberta. Aquilo que é conservado na tradição é a reserva racional da justificação, ou seja, as formações históricas da tradiçăo são o lugar da convalidação intersubjetiva dos juízos. "Os costumes são adotados livremente, mas nem se criam por livre determinação, nem sua validez se fundamenta nesta. Precisamente é isto o que chamamos tradição: o fundamento de sua validez." $45 \mathrm{~A}$ tradição é a sempre presente confirmação da historicidade que nenhum esforço finito do homem é capaz de esgotar - a tradição é a marca da nossa finitude.

44 Cf. Gadamer, op. cit., p. 349

45 Cf. Gadamer, op. cit., p. 348 . 


\subsection{A distância como possibilidade produtiva do compreender}

Gadamer nos ensina que "a compreensão começa ali onde algo nos interpela" e afirma que "esta é a condição hermenêutica suprema". ${ }^{46}$ Isso quer dizer que a compreensão se inicia com a estrutura lógica e ontológica da pergunta. Nós perguntamos quando nos sentimos interpelados por algo que não compreendemos; perguntamos quando somos capazes de realizar projeto e estamos dispostos a encontrar as raízes das nossas dúvidas: A pergunta é, pois, a condição hermenêutica originária porque com ela iniciamos o esforço hermenêutico, abrimos e mantemos abertas as possibilidades da compreensão.

Qual é, então, a importância da distância na elaboraçăo da pergunta e na abertura de suas possibilidades? Gadamer nos diz que "compreender significa, primeiramente, um entender-se na coisa e, apenas secundariamente, destacar e compreender a opinião do outro como tal". ${ }^{47}$ Ora, o esforço hermenêutico começa com uma pergunta, porque a partir do ato de perguntar começamos a tomar distância dos pré-juizos nos quais estamos imersos. E a primeira e fundamental barreira que deve ser transposta é o obscurecimento de nossos próprios pré-juizos; 0 reconhecimento dos pré-juizos é o que a hermenêutica denomina abertura e disposição fundamentais à compreensão ${ }^{48}$ ou "condição hermenêutica suprema".

O círculo hermenêutico se realiza no diálogo e o início do diálogo acontece no encontro com "o outro", no deixar-se interpelar por ele. Ali onde algo me interpela é o lugar em que reconheço a minha finitude, porque estou diante do que me fala sem que eu, de imediato, o consiga entender. Por ser interpelado, o intérprete desprega-se de si mesmo e projeta-se no outro. No ato de projetar-se acontece a suspensão dos pré-juizos. $\mathrm{O}$ que isso quer dizer? Que os próprios pré-juizos, que antes estavam encobertos, são postos no jogo 49 de pergunta e resposta, eles mesmos são questionados na sua validade e submetidos ao processo de esclarecimento, necessário ao "entender-se na coisa". A suspensão dos pré-juízos é o dar-se conta por parte do intérprete da sua "pertença" a uma tradição, da sua imersão na história. Essa consciência é profundamente produtiva ao círculo hermenêutico, pois, a partir dela, os pré-juízos perdem seu caráter obstruidor e passam a ser condição indispensável à compreensão.

46 Cf. Gadamer, op. cit., p. 369.

47 Cf. Gadamer, op. cit., p. 364 .

48 Quando Gadamer nos diz que o maior preconceito da filosofia da consciência è "o preconceito contra o preconceito", ele nos quer dizer que há dois tipos básicos de pré-juizos, aqueles que obstruem o circulo hermenêutico e aqueles que săo produtivos e, por isso, imprescindiveis a qualquer compreensão. $\mathrm{O}$ não-reconhecimento dos próprios prè-juizos é o prejuizo que maior obstáculo causa à compreensão, pois ele não permite o inicio do processo e nào desencadeia a pergunta inicial; isso quer dizer que o principal preconceito obstacularizador é aquele que deixa o intérprete fechado em si mesmo, pensando-se capaz de compreender o outro sem, contudo, deixar-se interpelar por ele.

49 Gadamer insiste no fato de que o deixar-se interpelar pela "coisa mesma" nảo é um mero ato de vontade subjetiva, mas tem como sua condiçâo o caráter de "pertença", de quem interpreta, ao chão comum de uma tradição, na qual está também inserido o que se quer interpretar. Por isso, diz Gadamer, "na realidade, o próprio pré-fuizo só entra realmente em jogo, porque jả antes estả submetido nele" (Cf. Gadamer, Verdad y metodo L, p. 369). 
"Só a distância no tempo toma possivel resolver a verdadeira questão critica da hermenêutica, a de distinguir os pré-juizos verdadeiros sob os quais compreendemos, dos pré-juizos falsos que produzem os mal-entendidos. Neste sentido, uma consciência formada hermeneuticamente terá que ser até certo ponto também consciência histórica, e trazer à consciência os próprios pré-juizos que a guiam na compreensão, a fim de que a tradição se destaque, por sua vez, como opinião distinta e ocupe assim o seu lugar. $" 50$.

Podemos entender, a partir deste ponto, que o encontro com o "outro", com o "estranho", conduz o intérprete a uma tríplice revelação: ele se revela para $s i$ mesmo (os seus próprios pré-juízos); "o outro" (aquilo pelo qual o intérprete se pergunta) se manifesta para ele e a tradição mostra-se como o lugar comum do intérprete e do interpretado. Essas três instâncias formam o círculo hermenêutico; todas são igualmente necessárias à compreensão; nelas imbricam-se passado, presente e futuro. Por isso, podemos dizer que a distância no tempo destaca, nas suas diferenças, as três dimensōes do círculo da compreensăo ("o si mesmo", "o outro" e a tradição) e, mais do que isso, esclarece os nexos que as condicionam. A distância é o que revela o outro de mim mesmo, isto é, o outro que participa do mesmo horizonte de sentido que eu. A distância é, ao mesmo tempo, ausência e presença: é ausência de compreensão que impulsiona o intérprete à compreensão, ou seja, o algo a ser interpretado tem do intérprete uma distância histórica objetiva e, por outro lado, ela é o que revela a presença de um mesmo sentido vinculante que envolve intérprete e obra. Sem distância não é possivel compreender, pois não se pode fazer mediação alguma para o que não se distanciou e ainda permanece imediato; por outro lado, só se compreende aquilo que pertence a uma mesma unidade de sentido; portanto, a distância que nos separa de uma obra a ser interpretada precisa ser explicitada para tomar possivel a interpretação.

Então, o que toma a distância produtiva no círculo hermenêutico? A primeira resposta é: a distância faz com que o pensamento se reconheça como verdadeiramente histórico, porque se torna capaz de pensar sua própria historicidade. Em outras palavras, a distância desprega o intérprete de si mesmo, joga-o na tradiçảo e torna possivel para ele jogar o jogo de encontrar os nexos que o vinculam a uma obra que ele quer interpretar. Gadamer deixa muito claro que compreender não é reproduzir ${ }^{51}$ (fielmente) um conhecimento do passado, mas é torná-lo produtivo no presente. Portanto, não se trata de superar a distância, pois ela é, objetivamente, distância histórica e, por isso, jamais pode ser superada, nem se trata de pensar a distância como um "abismo devorador", mas sim como um caminho "coberto pela continuidade da procedência e da tradição, cuja luz nos mostra tudo aquilo que nos é transmitido". 52

50 Cf. Gadamer, op. cit., p. 369.

51 A teoria hermenéutica do romantismo "pensava a compreensâo como reprodução de uma produção originária. Por isso, podia colocar-se sob a divisa de que é possivel se compreender um autor methor do que ele mesmo se compreendia". No entanto, Gadamer mostra que toda compreensão compreende de um modo diferente, pois todo intérprete compreende algo sempre a partir de seus próprios pré-juizos, quando, tomando distância deles, projeta-os produtivamente. Ou seja, toda compreensâo é nova produção e não simplesmente reprodução (Cf. Gadamer, op. cit., p. 366-367).

Cf. Gadamer, op. cit., p. 367. 
Parece paradoxal afirmar que a distância jamais pode ser superada e, ao mesmo tempo, dizer que "o sentido de um texto supera seu autor não ocasionalmente, mas sempre". Mas essas afirmaçőes, em vez de contraditórias, são complementares; podemos juntá-las da seguinte forma: 'a distância jamais pode ser superada, por isso, o sentido de um texto supera seu autor não apenas ocasionalmente, mas sempre'. Ora, vimos acima que a distância deve ser entendida como um caminho coberto pela continuidade da procedência e da tradição; portanto, o sentido de um texto, tanto não é produzido pelo intérprete, como também não está fechado no próprio texto; ele pertence à tradição na qual está inserido e só pode ser revelado quando são encontrados os nexos que existem entre os préjuizos produtivos do intérprete, o texto e a tradição, Por isso, a distância só é distância numa mesma tradição, num mesmo horizonte de sentido e, assim como não se pode prescindir da tradição, igualmente não se pode superar a distância.

"Compreender não é compreender melhor, nem no sentido objetivo de saber mais em virtude de conceitos mais claros, nem no da superioridade básica que possui o consciente a respeito do inconsciente da produçâa. Bastaria dizer que, quando se compreende, se compreende de um modo diferente. Este conceito da compreensão já rompe o circulo traçado pela hermenêutica romântica." 53

O círculo da compreensão não é cumulativo, não é um círculo que se fecha sobre si mesmo, não tem a forma de uma circunferência, mas sim de uma espiral, por isso "não é correto falar em compreender melhor", como se a verdade fosse um objeto a ser alcançado ao final do processo de elaboração da compreensão e de uma vez para sempre. Não se trata de um círculo epistêmico-metodológico, ${ }^{54}$ que se efetiva nos padrôes da relação sujeito-objeto, mas de um círculo ontológico-hermenêutico $0^{55}$ que explicita a prévia estrutura da compreensảo e concebe a verdade como o sentido possivel de ser manifestado e jamais esgotável. Isso quer dizer que "o circulo não é de natureza formal; não é subjetivo nem objetivo, mas descreve a compreensão como a interpretação do movimento da tradição e do movimento do intérprete". ${ }^{56}$

53 Cf. Gadamer, op. cit., p. 366-367.

54 Em Schleiermacher subjaz a idéia de um círculo hermenêutico na relação que se estabelece entre "parte" e "todo", "geral" e "particular" no processo de compreensão. No entanto. Schleiermacher ainda estava preso ao modelo epistemológico-psicológico da filosofia da consciência. Por isso, a circularidade da compreensão era ainda de natureza formal, de tal maneira que a relação "parte" e "todo" tinha seu fim na compreensão total. Ora, esse erro se deve ao fato de que, para Schleiermacher, a antecipação de sentido que guia nossa compreensăo de um texto é um ato da subjetividade e a tradiçăo é uma objetividade que pode ser presentificada, ficando sua concepção circular vulnerável à crítica de círculo vicioso.

"O giro ontológico da hermenêutica, a partir de Heidegger, explicita a idéia do círculo hermenêutico de tal forma que a compreensão do texto se encontra determinada continuamente pelo movimento antecipatório da pré-compreensăo. $\mathrm{O}$ círculo do todo e das partes não se anula na compreensão total, mas alcança nela sua realizaçăo mais autêntica. No sentido ontológico, o círculo descreve a compreensăo como a interpretação do movimento que explicita os nexos entre a tradição, 0 intérprete e a obra. Assim, o sentido da compreensão se gesta na história e a historicidade toma-se 0 "wh principio hermenèutico fundamental" (Cf. Gadamer, op. cit., p. 363). Cf. Gadamer, op. cit., p. 363. 
Com a tematizaçâo da "distância", Gadamer reforça a idéia de que a historicidade da compreensão é princípio hermenêutico fundamental. Se entendemos que só podemos nos compreender e dar-nos conta do "outro" na história e imersos em tradições, ou seja, como historicidade, compreenderemos também a força produtiva da "distância" na tradição enquanto provocadora da tensão entre "o estranho" e "o familiar". Essa tensão torna possivel o surgimento da pergunta que se lança na busca de uma unidade de sentido. Portanto, a distância provoca 0 processo de mediação entre o passado e o presente, entre a obra e o intérprete. A tradição realiza essa mediação; por isso, ela é "o verdadeiro tónos da hermenêutica", ${ }^{57}$ pois é o lugar onde acontece a mediaçăo da "distância".

\section{A fusão de horizontes na linguagem}

Para Gadamer o círculo da compreensão ganha sua plena explicitação na linguagem. Isso quer dizer que a linguagem é a casa do Ser que deve ser compreendido. É na linguagem que a consciência histórica emerge com toda sua agudeza; a linguagem é o lugar da efetivação do diálogo e da historicidade. A inesgotável possibilidade de sentido da linguagem a torna horizonte último da compreensão nas três dimensões em que ela se efetiva: compreensão (estrutura prévia), interpretação e aplicação. ${ }^{58}$

Vamos, então, seguir mostrando como a consciência histórica se realiza na linguagem e como na linguagem a história é sempre história efetiva, isto é, lugar da compreensão como acontecimento vivo e sempre aberto a novas aplicações.

\subsection{A consciência histórica}

A hermenêutica gadameriana tem a consciência histórica como seu núcleo central e como sua instância de produtividade. Com esse conceito Gadamer explicita uma concepção distinta da que tinha o historicismo; para ele, a história não é um depósito de acontecimentos passados, completados e canonizados e, conseqüentemente, não há sentido autêntico já dado de uma vez para sempre, que precise apenas ser passivamente descoberto. Pelo contrário, a consciência histórica é a dimensão sempre crítica da hermenêutica que entende a história como processo contínuo que jamais se cristaliza num passado distante e fechado. A consciência histórica é guardiã do $\operatorname{Ser}^{59}$ que sempre precisa ser compreendido; ela è a própria consciência da finitude.

Gadamer considera absurda a afirmação de que a história pode ser completamente trazida à consciência; para ele, a consciência histórica é "um momento da realização da compreensão", um momento que não pode ser "coisificado", mas

\footnotetext{
57 Ct. Gadamer, op. cit., p. 365.
}

58

Veremos a seguir que Gadamer considera a "aplicação" como um momento essencial e integral do processo hermenêutico, tanto quanto a compreensão e a interpretação, ou seja. compreender é sempre interpretar e interpretar é aplicar referências a uma situação concreta, pode-se dizer, portanto, que compreender é sempre também aplicar.

59 A consciência histórica é guardiã do Ser na medida que supera a ingenuidade da fé metodológica: crença num sentido (historicamente) dado como objeto e, por isso, passivel de ser metodicamente desvendado por um sujeito. 
sempre se renova em novos momentos. Já mostramos anteirormente como cada situação que exige uma interpretação coloca em movimento o círculo da compreensão, através da pergunta fundamental pelo outro, revelando simultaneamente ao intérprete que ele é o outro de si mesmo e que também precisa interrogar seus próprios pré-juizos, resultando daí a consciência de finitude e de "pertençca" a uma tradição, que o determina desde sua gênese e "convalida" sua interpretação.

É importante notar que a consciência histórica é uma tarefa e, como tal, exige um esforço contínuo para manter-se: "ser histórico quer dizer não esgotar-se nunca no saber-se". 60 A temporalidade é a abertura por onde entram os pré-juizos conscientes e irrefletidos; por isso, há uma necessidade permanente de "convalidação": confronto dos juizos prévios, testados anteriormente ou não, com situações concretas novas. O "novo" de uma nova situação concreta vem marcado por determinações históricas que só podem ser conhecidas quando se inicia um processo de interpretação para apurar o seu sentido imanente. A tradição não se esgota jamais e sempre que um intérprete faz um esforço hermenêtico para compreender algo, ela volta com toda sua força, exigindo dele a permanente disposição para superar a dificuldade, presente a cada nova situação:61 "uma consciência verdadeiramente histórica carrega sempre seu próprio presente":62 ter isso em mente é manter a consciência histórica atualizada.

Gadamer recupera o conceito de "aplicação" como problema hermenêutico fundamental exatamente porque esse conceito traz à tona a dificuldade que deve ser superada em cada situação concreta nova na qual se quer compreender algo. A "aplicação" é uma exigência hermenêutica que provoca o movimento63 contínuo no círculo da compreensão. A interpretação de um texto, de uma mensagem ou de uma obra do passado não se dá simplesmente com a aplicação metódica de técnicas, pois não se trata de um invólucro que guarda um sentido que pode ser simplesmente reproduzido, mas trata-se de algo que se abre a mim como indeterminação e que carece de aplicação a uma situação concreta para ser determinado.

"A aplicação não quer dizer aplicação ulterior de uma generalidade dada, voltada primeiro para si mesma, como a um caso concreto; mas ela é a primeira verdadeira compreensāo da generalidade que cada texto dado vem a ser para nós. A compreensão é uma forma de efetivação, e se sabe a si mesma como efetiva." 64

A importância do conceito de "aplicação" para a hermenêutica fica bem explicitada quando Gadamer recorre à ética aristotélica para mostrar a diferença entre os conceitos de phrónesis e episteme, isto é, entre saber moral e saber teórico. O que mostra Aristóteles na sua Ética a Nicômaco é que o saber da phrónesis

60 Cf. Gadamer, op. cit., p. 372

61 Para Gadamer o conceito de situação deve ser entendido como "tarefa que em cada caso reveste-se de uma dificuldade própria". Isso quer dizer que nunca ninguém se coloca de frente a uma sítuaçăo como se se colocasse em frente a um objeto acabado, mas, nela "alguém se encontra sempre numa situação cuja ilimitaçăo é uma tarefa a qual nunca se pode dar cumprimento por inteiro" (Cf. Gadamer, op. cit., p. 372).

62 Cf. Gadamer, op. cit., p. 376.

63 Para Gadamer, a mobilidade histórica da compreensão havia sido esquecida ou relegada a segundo plano pela hermenêutica romântica, apesar de se constituir como o ponto central de uma colocação hermenêutica adequada (Cf. Gadamer, op. cit., p. 380).

64 Cf. Gadamer, op. cit., p. 414. 
não é um saber teórico puro, independente da experiência, como é, por exemplo, o saber matemático; nāo é um saber que possa ser alcançado simplesmente pelo recurso a uma tekhne ou a um método objetivador; mas, pelo contrário, é um saber que exige do que sabe o enfrentamento de situações práticas (concretas), que devem ser vividas porque afetam diretamente e imediatamente aquele que conhece.

Aristóteles já sabia que o homem não dispõe de sỉ mesmo da mesma forma que dispõe de um objeto e, nesse ponto, ele estabelece a diferença entre phrónesis e episteme, assim, se para um artesão a "aplicação" de uma tekhne atinge melhores resuitados quanto mais conhecimento (experiência) ele tiver antes de aplicá-la, isto é, quanto mais a tekhne se mostrar superior à coisa que deve ser aplicada, maior será a autenticidade do produto final; para a consciência moral a experiência ou o conhecimento teórico prévio nunca basta para uma decisão moralmente correta. Como fica colocado, então, nesse contexto o conceito de "aplicação" se só se aplica aquilo que antes já se possui? A resposta a essa questão mostra onde quer chegar Gadamer com a recuperação desse conceito para a hermenêutica. Por um lado, Gadamer deixa claro que a compreensão tem na historicidade o seu fundamento, portanto, não se pode prescindir dos juízos prévios não se pode ignorar a "tradição" - isso significa que ele mantém, através do conceito hermenêutico de "aplicação", a idéia de um conhecimento ou experiência prévia que deve ser aplicada, mas, por outro lado, ele recupera a phrónesis aristotélica para mostrar que o homem não dispõe de si mesmo, porque é um ser sempre inacabado, em constante fase de construção, é uma tarefa permanente e, por isso, não pode dispensar a atividade prática no processo de autocompreensão.

O exemplo clássico de Aristóteles retomado por Gadamer para explicitar a diferença entre os dois tipos de saber é o da justiça: "o que é justo não se determina por inteiro com independência da situação que me pede justiça". O que esse exemplo deixa claro é que aquele que aplica a lei do Direito "numa situação concreta se verá obrigado seguramente a fazer concessōes sobre a lei em sentido estrito, mas não porque não seja possível fazer as coisas melhor, mas porque de outro modo não seria justo". ${ }^{65}$ Aristóteles mostra que a aplicação a priori da lei no Direito pode gerar injustiças abomináveis; portanto, nunca se poderá antecipar uma decisão antes de adentràr na situação concreta a que a lei deve ser aplicada. E Gadamer ratifica a posição aristotélica dizendo que "a lei é sempre deficiente, não porque o seja em si mesma, mas sim porque frente à ordenação a que se referem as leis, a realidade humana é sempre deficiente e não permite uma aplicação simples das mesmas". 66 Gadamer, então, reúne no conceito de "aplicaçẫo" os dois momentos indispensáveis à compreensão: o passado que deve ser compreendido a partir de tradiçōes e o presente em que o intérprete foi interpelado para fazer a interpretação. E com isso fica claro mais uma vez que a consciência histórica gera o homem compreensivo: aquele que não interpreta de fora da situação, mas que se deixa afetar por ela e só compreende desde a situação histórica concreta mesma.

65 Cf. Gadamer, op. cit., p. 389.

66 Cf. Gadamer, op. cit., p. 390. 


\subsection{A experiência como núcleo da consciência hermenêutica}

O conceito de experiência é retomado por Gadamer para justificar o estatuto histórico da hermenêutica. Nesse conceito fica esclarecido por que a compreensão adequada não esgota o sentido de um texto ou de uma obra do passado. Já vimos que tradição, intérprete e obra (coisa) são os três elementos centrais que constituem o círculo hermenêutico; vimos também que este círculo não se fecha sobre si mesmo, como uma circunferência, portanto, nenhum dos três elementos constitutivos é jamais eliminado. Agora veremos como este conceito torna possivel pensar o círculo com o modelo da espiral, através da manutenção da negatividade própria da critica, da consciência da finitude que marca o homem e da possibilidade permanente da pergunta.

$\mathrm{Na}$ discussão que Gadamer faz com a dialética hegeliana, ele mostra como o projeto de Hegel de transformar a filosofia em ciência desemboca numa abstração. $\mathrm{O}$ argumento de Gadamer è que Hegel assume a experiência como condição necessária para chegar ao idealismo absoluto no conceito e, por isso, "a dialética da experiência tem que acabar na superação de toda experiência que se alcança no saber absoluto, isto é, na consumada identidade de consciência e objeto"; ${ }^{67}$ portanto, para chegar ao saber absoluto, Hegel prescindiu da experiência originária que no início do processo "dialético" foi tomada como pressuposto necessário da Ciência, o que para Gadamer é insustentável, já que faz parte da essência da experiência a referência, sempre, a novas experiências.

"Ser histórico quer dizer não esgotar-se nunca no saber-se. Todo saber-se procede de
uma predeterminaçāo histórica que podemos chamar com Hegel "substância", porque
suporta toda opiniāo e comportamento subjetivo e em consequểncia prefigura e limita
toda possibilidade de compreender uma tradiçăo em sua alteridade histórica. A partir
disto, a tarefa da hermenêutica filosófica pode caracterizar-se como segue: tem que
refazer o caminho da fenomenologia do Espirito hegeliana mostrando que em toda
subjetividade há uma substancialidade que a determina."68

A recuperação desse conceito aponta na direção contrária daquela a que desembocou Hegel no idealismo absoluto ${ }^{69} \mathrm{O}$ status de Ciência adquirido pela filosofia de Hegel, no sentido de saber absoluto, positivo, não faz, segundo Gadamer, justiça à consciência histórica, nem à hermenêutica, pois a experiência não é aqui

67 Ct. Gadamer, op. cit., p. 431.

68 Cf. Gadamer, op. cit., p. 372

69 Gadamer registra o momento da aproximação da dialética hegeliana com a hermenêutica - o seu momento negativo - aquele em que a experiência tem a estrutura de uma inversåo da consciência, explicitando-se como movimento dialético: a compreensão que a experiêneia que é realizada com um "objeto" - para a hermenêutica este objeto deve ser entendido como alteridade e nāo como passividade - altera simultaneamente nosso saber e seu "objeto"; isso quer dizer que após uma experiência sabemos diferente e mais do que antes; portanto, a experiència acontece na unidade de contrários (o si-mesmo e o outro) e quer dizer precisamente isto. Entaăo, o que, para Hegel, faz da experiência urna inversão da consciência, nesse instante negativo da dialética, è o seu autoreconhecimento no "outro", no "estranho". No entanto, como para Hegel "o caminho da experiência da consciência tem que conduzir necessariamente a um saber-se a si mesmo que já não tenha nada distinto nem estranho fora de si", então, conclui Gadamer que a essência da experiência é pensada no sistema de Hegel, desde o início, a partir de algo no qual a experiência já está superada: a Ciência, o saber absoluto (Cf. Gadamer, op. cit., p. 431). 
pensada na sua radicalidade, enquanto negatividade irredutível - já que sua essência é negativa - e, portanto, ela não poderá ser ídentificada com a positividade da Ciência. Gadamer afirma, contra Hegel, que "a verdadeira experiência é aquela na qual o homem se faz consciente de sua finitude. Nela encontram o seu limite o poder fazer e a autoconsciência de uma razão planificadora". ${ }^{70} \mathrm{~A}$ experiência hermenêutica é essencialmente histónica e isso quer dizer que "o que está e atua na história realiza constantemente a experiência de que nada retorna" e, por isso, "toda expectativa e toda planificação dos seres finitos é, por sua vez, finita e limitada. A verdadeira experiência é a experiência da própria historicidade". ${ }^{71}$

Não vamos fazer neste momento uma discussão entre a hermenêutica e a dialética hegeliana. Interessa-nos agora mostrar como a experiência considerada na sua essência possui um particular sentido produtivo para a hermenêutica ${ }^{72} \mathrm{e}$ como esse conceito, radicalizado, faz justiça à historicidade da compreensão, distinguindo-se de qualquer saber que subtraia a negatividade e o espaço aberto da criticidade.

Uma afirmação gadameriana bastante sugestiva para o entendimento desse conceito é que "em sentido estrito não é possivel 'fazer' duas vezes a mesma experiência". Isso quer dizer que toda experiência começa com uma pergunta que, para ser verdadeiramente pergunta, não pode ter uma resposta por antecipação; portanto, a experiência é abertura ao novo dentro de um horizonte de sentido em que a pergunta por algo se faz possível. Uma coisa já conhecida não pode suscitar uma pergunta, já que toda pergunta aponta para o desconhecido; por isso, uma experiência nova só acontece com uma pergunta nova. Somente um fato novo (desconhecido) e imprevisivel pode proporcionar ao que possui experiência uma nova experiência.

"A experiência é, pois, experiência da finitude humana. É experimentado no autêntico sentido da palavra aquele que é consciente desta limitação, aquele que sabe que não é senhor nem do tempo nem do futuro; pois o homem experimentado conhece os limites de toda a previsão e a insegurança de todo plano. Nele chega a sua plenitude o valor da verdade da experiência."73

Essa magnífica definição de experiência tem uma base profundamente antidogmática, porque pressupõe a própria experiência como seu fundamento e supõe sempre novas experiências possiveis e passíveis de suscitarem novas compreensões. Mas é preciso justificar essa definição e desconstrui-la para que seja possivel perceber o seu alcance.

70 Cf. Gadamer, op. cit., p. 433.

71 Cf. Gadamer, op. cit., p. 434.

72 Gadamer considera que o conceito de experiência ficou minimamente preservado do esclarecimento subjetivo da Ilustraçăo, apesar de ter tido sua essência encoberta pelos modelos do esclarecimento. Para a ciência ilustrada a experiência deve ser objetivada e passivel de reprodução, isso é o mesmo que dizer que a experiência deve ser considerada naquilo que se retém e que não foge ao controle metodológico, portanto, que a experiência enquanto tal deve ser superada. Nesse sentido, pode-se dizer que a experiência năo é ciência, mas sim seu pressuposto necessário; a ciência é aquilo que é retirado (positivado) no processo de negaçăo da experie̊ncia. Tomar a experiência como pressuposto da ciência não deve implicar sua negação e reduçăo à ciência, já que "a verdadeira experiência é sempre negativa".

73 Cf. Gadamer, op. cit., p. 433. 
Se retomarmos a ontologia fundamental de Heidegger lembraremos que ali a temporalidade é um modo de ser do eis-aí-ser, e isso significa que o histórico não é algo que se impõe de fora, mas ser histórico é caracteristica estrutural do ente da temporalidade. Desse modo, a experiência ontológica é a própria experiência da abertura estrutural; e, nesse sentido, é a experiência da finitude. ${ }^{74}$ Porque temos sempre um horizonte à frente, podemos olhar e ver para além de nós mesmos e não esgotamos jamais as possibilidades que se nos apresentam, nisso consiste a radical experiência da finitude.

A experiência mais fundamental é aquela de que estamos projetados à possibilidade de experimentar aquilo que nos ameaça. Da mesma forma, aquele que tem consciência de que não é senhor nem do tempo nem do futuro, é experimentado no autêntico sentido da palavra, pois é capaz de reconhecer o que verdadeiramente é real: aquilo que năo pode ser revogado por atos de vontade individual, porque fala por si mesmo enquanto alteridade. ${ }^{75}$ Assim, a verdadeira experiência explicita os limites de qualquer planificação determinada da razão; todo planejamento encontra seu limite no aberto horizonte de possibilidades de experimentar o diferente do planejado.

$\mathrm{Na}$ experiência o "eu" e o "outro" se nivelam enquanto possibilidades de experimentar; tanto o "eu" quanto o "outro" são afetados no encontro. Agora, já podemos perguntar por este horizonte comum que possibilita a fusão de horizontes na experiência do diálogo. Que "lugar" é este que se constitui como a própria abertura à experiência da finitude? Gadamer nos diz que este "lugar" é a linguagem, onde a finitude emerge e o sentido se descobre. A linguagem é o campo onde se dá o diálogo; pertence a ela o modelo ontológico do jogo, portanto, ela não é apenas meio para um outro fim, mas é meio e fim de qualquer compreensão possivel; assim como o jogo só acontece ao ser jogado, assim também a fusão de horizontes só se faz como acontecimento da linguagem.

\subsection{A compreensão como experiência na linguagem}

A frase epígrafe para o que queremos expor agora é.: "o ser que pode ser compreendido é linguagem". ${ }^{76}$ Gadamer descobre na linguagem o centrum da hermenêutica. É necessário, então, compreendermos esta frase para que possamos chegar ao núcleo ontológico da compreensão.

74 Gadamer considera a dor e o sofrimento grandes "pedagogos" da experiência ontológica da finitude. Padecendo aprendemos os próprios limites de ser humano. Por isso, ele reconhece o profundo sentimento religioso que se manifesta na origem da tragédia grega: "o que o homem aprenderá pela dor não é isto ou aquilo, mas sim a percepção dos limites do ser homem, a compreensão de que as barreiras que nos separam do divino não podem ser superadas" (Cf. Gadamer, op. cit., p. 433).

75 A consciência hermenêutica é antidogmática porque nela o outro não pode ser cercado pelo "eu". mas sempre será o "tu" capaz de me afetar. É nesse sentido que a hermenêutica entende como verdadeira a experiência que afeta quem experimenta, dela ele não sai ileso. $\mathrm{B}$ o que me afeta autenticamente é aquilo que não se dá como objeto da minha manipulaçảo, controlável por mim, mas. ao contrário, é aquilo que eu não pude prever para me prevenir, é o "tu" na sua inteireza. "A abertura para o outro implica, pois, o reconhecimento de que devo estar disposto a deixar valer em mim algo contra mim, ainda que não haja nenhum outro que o vá agir contra mim."

Cl. Gadamer, op. cit., p. 587. 
Nossa análise se fará através de três palavras modelares para o entendimento do que seja linguagem para a hermenêutica. Gadamer nos diz que a linguagem é, originariamente, acontecimento, especulação e abertura, numa palavra, a lingüisticidade é a finitude que marca a Humanidade.

A linguagem é acontecimento porque traz á palavra o sentido da experiência vivida, não como algo prẻ-existente que simplesmente é trazido ao conhecimento, mas como algo novo que se descobre na própria articulação lingüistica. O sentido do acontecimento como evento significa que a linguagem é centro originário do sentido manifesto e não apenas meio designador de um sentido já dado. $\mathrm{O}$ evento vai se constituindo à medida que está acontecendo; 0 acontecimento, à medida que se dá, também se perde; quando se manifesta, já se ocultä; ${ }^{77}$ por isso, a linguagem nunca será mero objeto de manípulação, pois jamais está à inteira disposiçăo de um sujeito. A linguagem é o ser que se compreende e não o ser que se possui.

Gadamer toma a palavra poética para ilustrar o sentido de acontecimento da linguagem. ${ }^{78} \mathrm{~A}$ poesia realiza a emancipação da palavra poética; o leitor de uma poesia não está interessado na opiniẫo e vivência do seu autor, mas naquilo que a poesia mesma comunica enquanto palavra poética e é nesse sentido que esta palavra está originariamente emancipada de toda e qualquer configuração determinista. A poesia acontece sempre de novo, como nova poesia, quando é experimentada; a poesia comunica uma unidade de sentido que se realiza sem se esgotar e que só pode ser alcançada pela compreensão. Assim, o modo de ser da linguagem é especulação.

Para Gadamet "é especulativo o que não se entrega direta e imediatamente à solidez dos fenômenos ou à determinação fixa do que se opina em cada caso, mas sim que sabe refletir". ${ }^{79}$ Ora, uma frase especulativa não é aquela que diz algo de algo, portanto, não é uma frase enunciativa, mas é aquela que "representa um novo aspecto de um novo mundo". Isso quer dizer que uma idèia especulativa hão é uma atribuição de uma determinaçăo fixa caracterizadora de um sujeito ou de uma propriedade de um objeto, mas, ao contrário, é uma idéía sempre em movimento, um movimento ao mèsmo tempo relativo (a um determinado referencial) e, por isso mesmo, inconcluso.

Uma citação de Hölderlín, feita por Gadamer, mostra muito bem em que sentido a poesia reúne o caráter de acontecimento, especulação e abertura referentes à linguagem:

77 Imaginemos uma explosấ de fogos de artificio como ilustração do que significa acontecimento para a hermenêutica. A beleza e a luminosidade dos fogos sâo eventos que acòntecem na mesma medida que desaparecem; a festa que se dá no ar é fugaz, pode ser vivida e compreendida em sua beleza e plenitude, mas não pode ser possuida; e exatamente porque não se torna um objeto de posse é que pode ser compreendida como festa e celebraçāo.

E preciso pontuar que quando Gadamer tematiza a Arte no primeiro capitulo de Verdade e Método. ele quer superar a dimensăo estética atribuida à obra de arte para recuperar a unidade entre o seu "em si" e sua "aparente manifestaçâo": "o ser da obra de arte nào era um ser em si que se distinguisse da sua reprodução ou da contingência de sua manifestação; só uma tematização secundária tanto de um quanto de outro pode conduzir a essa "distinçăo estética'" (Cf. Gadamer, op. cit., p. 568).

Cf. Gadamer, op. cit., p. 558. 
"Quando o poeta se sente captado em toda sua vida interna e externa pelo tom puro de sua sensibilidade originária e olha então a seu redor, para o seu mundo, este se lhe parece também novo e desconhecido; a soma de todas as suas experiências, de seu saber, de seu contemplar, de sua reflexâo, arte e natureza, como se the representam nele e fora dele, tudo aparece como se fora a primeira vez, sem conceitos, sem determinaçăo, resultando em pura matéria e vida, presente. $\mathrm{E}$ é importantíssimo que neste momento não tome nada como dado, năo parta de nada positivo, e que a natureza e a arte, tal como as têm aprendido antes e as vẻ agota, năo fale antes de que para ele exista uma linguagem [...]."80

Essa citação mostra o que não é uma palavra poética, ou seja, a poesia não designa algo que já existe, não é uma cópia, nem uma reprodução. E, ao mesmo tempo, diz o que é uma palavra poética sem, contudo, defini-la: a enunciação poética é especulativa, é a abertura para uma "nova" experiência, é a visão de um novo mundo, é a apreensão de um sentido inédito. A poesia traz à tona um novo horizonte a partir das experiências e saberes anteriores, provocando uma ampliação que torna todo o antes uma novidade, dando-lhe nova configuração, provocando uma experiência nova e uma fusão de horizontes. A enunciaçăo poética é especulativa porque não toma as coisas como dadas e positivadas, mas como abertas e prenhes de negatividade. A produtividade da linguagem poética reside na fecundidade da palavra, fecundidade que pertence ao núcleo originário da linguagem enquanto tal. Isso significa dizer que a linguagem artística é modelar para a hermenêtica, mas não quer dizer que ser especulativo - ser outro de si mesmo - auto-representar-se, ser enunciação de sentido, seja característica restrita à arte, mas é o modo de ser de tudo que pode ser compreendido, o que na arte aparece de forma explícita.

A linguagem é centro ${ }^{81}$ da hermenêutica porque é, também, seu início e seu fim. Nada que é falado ou representado ou enunciado pela linguagem tem sentido fora dela. A linguagem é abertura na medida em que não pode ser esgotada e, tambêm, porque não pode ser concebida como exterioridade fixada fora dos falantes. As afirmações feitas em frases e enunciados são combinações determinadas na infinidade de combinações possiveis da linguagem. Por ísso, a linguiisticidade nos traz a consciência da finitude, porque somente sendo finitos podemos buscar sentido, viver experiências novas, levantar perguntas, dialogar e vislumbrar o infinito.

Gadamer retoma dois conceitos da metafisica clássica para ilustrar a linguagem como o ser que pode ser compreendido sem ser jamais possuído e, portanto, como o infinito que confirma a nossa condição de historicamente finitos. Ele lança mão dos conceitos de Belo e de Verdade e, numa desconstrução magistral desses conceitos, afirma o caráter universal e ontológico da hermenêutica.

80 Ct. Gadamet. op. cit., p. 562-563.

81 Para Gadamer a linguagem é centro đa hermenêutica e pelo seu caráter universal é centro da fllosofia mesma. Isso significa que a linguagem reúne o "eu" e o "mundo"; na linguagem homem e mundo "aparecem em sua unidade originána". Essa colocaçào è extremamente significativa à medida que a sua principal consequeéncia é que o sentido se tealiza na linguagem e nunca fora dela; murido e homem se descobrem simultaneamente em relaçâo na linguagem e isso afirma a finitude como marca ontológica da Humanidade (Ct. Gadamer, op. cit., p. 567). 
Lembremos da frase epígrafe citada: "o ser que pode ser compreendido é linguagem". Considerando que a linguagem tem uma estrutura especulativa, isso quer dizer que ela é tal que se apresenta por si mesma à compreensão: "ascender à linguagem não quer dizer adquirir uma segunda existência". Portanto, tudo que é linguagem é especulativo: "trata-se de uma unidade especulativa, de uma distinção em si mesma: ser e representar-se, uma distinção que, sem dúvida, tem que ser ao mesmo tempo uma indistinção". ${ }^{22}$ Baseado nisto, Gadamer propõe o conceito de Belo para ilustrar esse caráter universal e ontológico da compreensão.

É belo aquilo cujo valor é evidente por si mesmo. Vale recordar que o uso da palavra evidente já mostra que uma coisa que se evidencia como bela não carece de exteriores justificações, e só por isso é evidente e bela. Disso resulta que o Belo não é meio para uma outra coisa, mas é fim em si mesmo. O Belo não é notado a partir de uma luz que brilha de fora e o foca, mas só é Belo enquanto ${ }^{33}$ tem luz própria.

Gadamer retorna a Platão e recorda que ali o Belo é determinado com os conceitos de medida, adequação e proporcionalidade; também Aristóteles apresenta o Belo como ordem, correta proporcionalidade e determinação e ilustra com a matemática. Ora, a metafísica antiga afirma o Belo em si como auto-evidente e diz das coisas belas que o são por participação ou adequação ao Belo em si. A mesma idéia é desenvolvida pela metafísica medieval, onde beleza e bondade se confundem e são o ser transcendente. No entanto, Gadamer sustenta a idéia originária da auto-evidência do Belo e da luz própria que ele é, mas provoca um giro hermenêutico nessa concepção ao afirmar que "o Belo não apenas aparece naquilo que tem uma existência sensivel e visível, mas é de tal forma que somente em virtude disto é realmente belo". 84

Gadamer deixa claro que "o aparecer não é apenas uma propriedade do que é belo, mas é sua verdadeira essência”. Não há, pois, como na metafísica clássica, uma distinção entre o Belo em si e a coisa bela, mas, ao contrário, o Belo só é em si na coisa na qual aparece, por isso é, ao mesmo tempo, idêntico e distinto da coisa; idêntico porque aparece na coisa como realmente é e distinto porque é mais: é igualmente belo em múltiplas coisas. A relação entre beleza e coisa bela deixa de ser exterior e "a-histórica" e passa a ser uma relação gestada no interior da linguagem, no mundo, onde nada é fora da lingüisticidade. Para ilustrar isto, Gadamer mostra que a beleza tem o modo de ser da luz:

"Isto não só quer dizer que sem luz não pode aparecer beleza alguma, que sem ela nada pode ser belo. Quer dizer também que no belo a beleza aparece como luz, como brilho. A beleza se induz a si mesma à manifestação. De fato o modo de ser geral da luz consiste precisamente nesta reflexão em si mesma. A luz não é só a claridade do iluminado, mas sim, enquanto faz visivel outras coisas, é visível ela mesma, e não o é

82 Cf. Gadamer, op. cit., p. 568.

83 A afirmaçăo: "o Belo só é belo enquanto tem luz própria", ressalta o modo de ser histórico do Belo. A conjunção enquanto marca bem esse caráter temporal. Isso ressalta a unidade originária do "eu" e do "mundo" na linguagem, porque, sendo mundano, o Belo pertence ao universo de sentido enunciado na linguisticidade do mundo; portanto, o Belo năo é um dado exterior à relaçăo "eu". "mundo", mas só se realiza no interior (intransponivel) dessa relaçăo.

Cf. Gadamer, op. cit., p. 575. 
de outro modo que precisamente enquanto faz visiveis outras coisas". "Deste modo é coisa da constituiçāo reflexiva própria do seu ser que a luz reúna o ver e o visivel, e que sem ela nāo exista nem um nem outro."85

A citação acima ilustra plenamente o que Gadamer pretende dizer da linguagem ao tomar o Belo como seu modelo ontológico. A linguagem radica em si a historicidade; tudo o que pode ser compreendido é linguagem e somente enquanto historicidade pode ser encontrado e comunicado. Assim como a luz só se torna visível na claridade do iluminado, do mesmo modo o sentido de uma enunciação lingüística só vem à tona na aplicação a uma coisa determinada, no círculo da compreensão. A luz que faz as coisas aparecerem como compreensiveis e luminosas é a luz da palavra; sem ela as coisas não têm sentido, não são coisas, são escuridão.

Da analogia feita por Gadamer entre o modo de ser da linguagem e o Belo, podem ser tiradas duas conclusões sumamente significativas para o entendimento do que seja a compreensão hermenêutica: uma é que tanto o Belo quanto o modo de ser da compreensão possuem caráter de evento; ${ }^{\circ}$ a outra é que a experiência hermenêutica tem a mesma imediatez que caracteriza a experiência do Belo, e nisto reside a sua verdade.

Assim como o conceito de Belo faz prefigurar a universalidade do modo de ser da compreensão, da mesma forma acontece com o conceito de verdade. Aquí, mais uma vez, Gadamer recorre à concepção de verdade da metafísica' è dela retira o que pode ser produtivo para a experiência hermenêutica. Ele se remete mais uma vez a Platão, lembrando que "o Belo, o modo como o bem aparece, se faz patente em si mesmo em seu ser, representa-se. O que assim se representa não fica como distinto de si mesmo enquanto se tem a si mesmo representado. Não é uma coisa para si e outra distinta para os demais". ${ }^{87}$ Gadamer ressalta aqui que a característica metafisica do Belo rompeu com a dicotomia entre "idéia" 88 e aparência; ele lembra que ali onde Platão invoca a evidência do belo, não é necessário manter a oposição entre o Belo em si e a sua imagem, pois o Belo mesmo pōe e supera simultaneamente esta oposição. A partir dessa posição Gadamer trabalha o conceito de verdade.

A verdade é, assim como o Belo, aquilo que se representa a si mesmo. Não é uma atribuição de algo a algo, não se constituí numa relação de sujeito e objeto, pois nisto consiste a possibilidade do erro e da falsidade, mas é a autorepresentação. A verdade é, portanto, auto-evidente, poís não há nada de fora que, sendo-lhe atribuído, seja capaz de modificar a sua essência. Como entender isto? Gadamer recorre ao modelo do jogo para mostrar que qualquer dizer de um jogo sem o jogo é vazio e carente de sentido, pois o jogo só se evidencia ao ser jogado, sua verdade consiste no seu acontecer e, enquanto acontecimento, a verdade do jogo é auto-evidente - "representa por si mesmo o que é, o que foi e o que vai ser, e atesta por si mesmo o que anuncia". É este, portanto, o sentido que tem a verdade na compreensão.

85 Cf. Gadamer, op. cit., p. 576.

86 Ver a nota explicativa sobre "acontecimento" no subtitulo anterior.

87 Cf. Gadamer, op. cit., p. 581.

88 Gadamer lembra que a "idéia pertence a uma ordenação do ser que se destaca sobre a corrente dos fenómenos como algo consistente em si mesmo" (Cf. Gadamer, op. cit., p. 582). 
A verdade, assim como a beleza, não é uma entidade transcendente e não se encontra entificada em nenhum lugar, mas só é enquanto se representa; podemos dizer que só se dá quando pode ser aplicada, por isso, a verdade é acontecimento. Bom, neste ponto podemos mais uma vez configurar o acontecer da beleza e da verdade hermenêutica como estando fundamentado na experiência ontológica da finitude humana. Não teria sentido falar da experiência do Belo e do verdadeiro para um "espírito absoluto", pois, como já vimos, é próprio da essência da experiência encontrar o novo e o diferente no experimentado; e o absoluto, por ser infinito, não pode experimentar o diferente que nele não há. Gadamer, aqui, considera conseqüente a superação da arte pelo conceito na filosofia hegeliana, já que esta se constitui corno um saber infinito e absoluto. Dessa forma, a experiência do Belo e o acontecimento da verdade estão reservados apenas à finitude humana.

Na desconstruçāo feita do conceito de verdade Gadamer realiza o sentido do título do livro Verdade e método ${ }^{89}$ A verdade aqui é uma instância especulativa que contém a fecundidade do pensamento hermenêutico, na medida que não pode ser possuida, mas apenas compreendida. Podemos dizer com Gadamer que assim como a ambigüidade de um oráculo não é seu ponto frágil, mas, ao contrário, justamente sua força, da mesma forma se dá com o movimento que caracteriza a verdade e faz aparecer seu modo de ser sempre inconcluso, pois nisto reside sua força especulativa, incompatível com qualquer atitude metodológica reprodutiva e controladora. Ėm Gadamer a verdade não é conseqüência aditiva do método, más è verdade contra o método.

Agora já podemos entender o sentido da expressão fusão de horizontes. Éssa expressão encontra sua legitimação na frase que assumimos como epigrafe: $\mathrm{o} \mathrm{ser}$ que pode ser compreendido é linguagem, porque somente entendendo que a linguagem é o centró da especulaçáo hermenêutica, portanto, o mais amplo e, ao mesmo tempo, o mais próximo horizonte de compreensão possivel, é que podemos entender que significa a fusão de horizontes. Gadamer entende por horizonte "o âmbito de visắo que abarca e encerra tudo que é visivel a partir de um determinado ponto". 90 Vale lembrar que este conceito é fecundo para a hermenêutica na medida que nele está contida a idéia de movimento, já que o horizonte se afasta na mesma proporção daquele que se move ao seu encontro; ou seja, o horizonte, não pode ser possuido, pois nisto consistiria sua destruição. A partir disto, podemos ver que horizonte tem a ver com compreensão, e todo processo de compreensão requer um horizonte histórico que the sirva como ponto de partida. Ora, já vimos anteriormente o que sằo os pré-juizos e qual a importância hermenêutica da tradição, agora podemos afirmar que tanto os pré-juizos quanto a tradiçăo são horizontes que tornam possivel a compreensão.

89 Verdade e Método inicia com a temática da arte para chamar atenção do seu caráter especulativo, e no final (no último capitulo do primeiro volume) esta caracteristica da arte é universalizada na Linguagem. A Linguagem passa a ser entendida como o centro onde o "eu" e o "mundo" encontram sua unidade originária; nesse sentido, a especulaçåo própria da linguagem não é o centro somente da hermenêutica filosófica, mas de toda filosofia.

90 Gadamer lembra que a filosofia tem utilizado o termo horizonte desde Nietzsche e Husserl para caracterizar a vinculaçâo do pensamento a sua determinidade finita e a sua possibilidade de projeção e ampliação (Cl, Gadamer, op. cit., p. 372-373). 
Quando nos voltamos para algo que desejamos compreender, estamos iniciando um processo dialógico. Todo diálogo é um encontro cujo centro é a linguagem, e todo encontro no interior da linguagem é uma experiência do "eu" com o "mundo", do "eu" no "mundo"; é, pois, uma relação tensa aquela que se estabelece entre o "eu" e o "outro", na intenção de romper com os limites de uma consciência ingênua do presente finito que ocultam esta tensão e de projetar um horizonte para além desta situação. Ganhar um horizonte quer dizer sempre aprender a ver para além do que está próximo. Significa superar a imediatez fazendo mediaçōes; isso não quer dizer abandonar o horizonte presente, mas, ao contrário, vê10 melhor, ampliando-o e integrando-o num todo maior e em padrões mais apropriados.

O lançar-se ao encontro de um outro horizonte tem como condição de possibilidade o caráter especulativo da linguagem. Desse modo, a fusão de horizontes não significa dissolução do "eu" no "outro" e nem è um encontro justaposto de dois horizontes, mas é, sim, a interpenetração de ambos como acontecimento da linguagem. Ora, isso mostra que na realização de uma compreensão o "eu" media-se a si mesmo no "outro", descobrindo seus pré-juizos e encontrando-se no interior de uma tradiçăo que é linguagem para além dele e, nesse momento, dá-se também a compreensão do "outro". Aí acontece simultaneamente a fusão de horizontes e sua própria superação, pois qualquer compreensão sempre se dá através de uma determinada aplicação histórica e, assim, quando uma nova aplicaçăo for feita nascerá umá nova experiência lingüística no tenso movimento da "fusão horizôntica".

\section{Referências bibliográficas}

ARISTÓTELES. Ética a Nicômacos. 3. ed. Brasilia: Editora da UnB, 1992.

BLEICHER, Josef. Hermenéutica contemporánèa. Lisboa: Ediçōes 70, 1992.

BUBNER, Rügiger. La filosofia alemana contemporanea. 2. ed. Madri : Cátedra, 1991.

CORETH, Emarich. Ouestốes fundamentais de hermenêutica. São Paulo: EDUSP, 1973.

STEIN, Emildo. Seis estudas sobre Ser Tempo. 2. ed. Petrópolis: Vozes, 1990.

- Instauração do sentido. Porto Alegre: Movimento, 1977.

—_. Aproximaçб̄es sobre hermenéutica. Porto Alegre: EDIPUCRS, 1996.

- A caminho de uma fundamentação pós-metafisica. Porto Alegre: BDIPUCRS, 1997.

GADAMER, Hans G. Verdad y metodo. Salamanca: Sigueme, 1994. v. 1 e 2.

HEIDEGGER, Martin. Ser e tempo, 4. ediçào. Petrópolis: Vozes, 1996. Partes I e II.

- Identidad y diferencià. 2. ediçâo bilingủe. Barcelona: Anthropos, 1990.

(Coleçăo Os Pensadores)

HUIZINGA, Johan. Homo Iudens, 6. ed. Madri: Alianza, 1996.

OLIVEIRA, Manfredo Araújo de. Reviravolta lingüistico-pragmática na filosofia contemporånea. São

Paulo: Loyola, 1996.

TAYLOR, Charles. Argumentos filosoficos. Barcelona: Paidós, 1997.

TUGENDHAT, Emst. Autoconciencia y autodeterminación. Madri: Fondo de Cultura Bcónomica, 1993.

VATTIMO, Gianni - Más allá de la interpretación. Barcelona: Ediciones Paidós, 1995.

ㄴ. (org.). Hermenéutica y racionalidad. Bogotá: Norma, 1994. 